Journal of Clinical Investigation

Vol. 42, No. 5, 1963

\title{
THE ROLE OF AUTONOMIC AND MYOCARDIAL FACTORS IN CARDIAC CONTROL *
}

\author{
BY THOMAS A. BRLCE, $\div$ CARLETON B. CHAPMAN, ORLAND BAKER, AND \\ JOSEPH N. FISHER \\ (From the Cardiopulmonary Laboratory, Department of Internal Medicine, University of \\ Tcras Southwestern Medical School, Dallas, Tex.)
}

(Submitted for publication March 8, 1962 ; accepted January 24, 1963)

The classical Starling hypothesis, based on studies of isolated heart preparations, assigns the dominant role in cardiac control to the functional relation between end-diastolic fiber length and stroke work; it acknowledges the influence of autonomic factors, but considers them less fundamental than the intrinsic myocardial factor $(1,2)$. At the other extreme is the view that cardiac response to stress in the intact human being is largely a matter of change in rate, the autonomic factor almost completely overshadowing any intrinsic mechanism (3). Graded treadmill studies in normal human subjects, however, suggest that both an increase in stroke volume and in pulse rate are employed in adapting to exercise (4). The increase in stroke volume is not linear with the increase in severity of exercise, as has been pointed out by Rushmer (5). Even in experimental animals, the role of increase of stroke volume and, by inference. of intrinsic myocardial factors, is difficult to assess because such factors, if present, are obscured by powerful autonomic effects. The need for quantitative studies in which autonomic influences can be eliminated in otherwise intact animals, and in which change in ventricular volume can be measured directly, has often been noted and was partly met by earlier work from this laboratory (6). In addition, Ashkar and Hamilton recently reported that cardiac denervation in dogs caused restriction of "the normal increase in oxygen consumption and cardiac output with exercise" (7). Donald and Shepherd obtained similar results. also in dogs, and noted that after cardiac denervation, adlaptation to exercise depended solely on increase in stroke volume (8). The following project was undertaken primarily

\footnotetext{
* Supported by L. S. Public Health Service grant $\mathrm{H}-3701$.

$\dagger$ Present address: Department of Medicine, Wayne State University, Detroit, Mich.
}

to clarify further the nature of cardiac adaptation to exercise in dogs that were intact except for various types of cardiac denervation.

\section{METHODS}

The basic techniques utilized for study of left ventricular function were described previously $(9,10)$. Male mongrel dogs were anesthetized with a mixture of $\alpha$-chloralose and urethane, and tracheal intubation was performed. A no. 9 bird's-eye catheter was inserted from the external jugular vein into the main pulmonary artery for injections of contrast material, and a no. 7 plain catheter was passed through the carotid artery into the left ventricle for pressure recordings. The animal was then suspended horizontally between two cinefluorographic units so that right and left anterior oblique views of the heart were simultaneously recorded. Breathing was controlled throughout the period of suspension by a Thompson pump respirator with constant warm nebulization. Approximately $2 \mathrm{ml}$ of $90 \% \mathrm{Hy}-$ paque ${ }^{1}$ solution per $\mathrm{kg}$ of weight was injected rapidly into the pulmonary artery, and photographs were taken at 30 frames per second for 6 to 8 seconds. Left ventricular pressure, an electrocardiogram, and, in some animals, the intraesophageal pressure were recorded simultaneously.

After the resting study, dogs were exercised by applying electrical impulses ( 2 per second at $175 \mathrm{v}$ ) to the thigh muscles, causing vigorous kicking of the hind legs. Exactly the same stimulus was applied in each study. The standard test causes oxygen consumption to increase about four times the resting value. At rest, 13 normal anesthetized dogs showed an oxygen intake of $6.20 \pm 1.59 \mathrm{ml}$ per $\mathrm{kg}$ per minute. With simulated exércise of the sort described, intake rose to $25.47 \pm 5.28 \mathrm{ml}$ per $\mathrm{kg}$ per minute. The test was standardized in this manner since, owing to the design of the experiment. oxygen intake could not be measured during the actual volume measurements. The test is therefore comparable to standard exercise tests used in human exercise studies that produce approximately the same increase in oxygen consumption from subject to subject. Exact oxygen consumption in individual animals was not crucial, since each animal is his own control and since minute volume estimations were based on stroke volume and pulse rate

\footnotetext{
${ }_{1}$ Diatrizoate sodium.
} 
rather than on oxygen intake and arteriovenous oxygen differences.

After the base-line studies, five dogs were subjected to cardiac sympathectomy in two stages. Under pentobarbital anesthesia, a unilateral thoracotomy was made in the third or fourth intercostal space and the thoracic sympathetic chain was excised from the level of $T-6$ to the inferior cervical ganglia. The sympathetic trunk lying in the vagus nerve and ending in the inferior cervical ganglion was dissected free and removed just cranially to the middle cervical ganglion. Two weeks later sympathectomy on the opposite side was carried out in the same manner.

Single-stage thoracic sympathectomy, with a sternumsplitting approach, carried a very high mortality and was abandoned early in the project.

Ten to 14 days after the second operation, when the dogs had been active and eating well for at least a week, the cineangiofluorographic studies were repeated. The technique was the same as before except that, prior to suspension before the cameras, loops of umbilical tape were placed around both vagi in the neck region. After resting and exercising runs had been completed in the sympathectomized state, the animal was allowed a 30 - minute interval to reach a new resting level; both vagi were then cut, and resting and exercising studies were repeated.

Animals studied with vagectomy alone were prepared by isolating the cervical vagi before cineangiofluorography was performed. After base-line studies at rest and during exercise, the vagi were severed, and the procedure was repeated. The completeness of vagectomy was established by iv administration of atropine (0.6 $\mathrm{mg}$ ). Vagectomy was assumed to be complete if the drug produced no further increase in rate. Bilateral vagectomy, alone or combined with cardiac sympathectomy, was usually followed by death within 48 hours, apparently due to pulmonary congestion and atelectasis. For this reason long-term effects of vagectomy were not studied.

Left ventricular volume was calculated by a previously published method (9). The original $35-\mathrm{mm}$ images (LAO and RAO, left and right anterior oblique) were traced frame by frame with a reference plate of known size to correct for photographic distortion. Tracings were fed into an electronic scanner-computer (11) that measured the diameters of each pair of tracings at $1.0-\mathrm{mm}$ intervals from top to bottom and simultaneously

TABLE I

Comparison of measurements of left ventricular function in 14 intact anesthetized dogs (average weight, $16.1 \mathrm{~kg}$ ) at rest and during mild exercise

\begin{tabular}{|c|c|c|c|c|c|c|c|c|}
\hline & & & \multicolumn{2}{|r|}{$\begin{array}{l}\text { Rest } \\
80 \text { cycles }\end{array}$} & \multicolumn{2}{|c|}{$\begin{array}{l}\text { Exercise } \\
82 \text { cycles }\end{array}$} & \multicolumn{2}{|c|}{$\begin{array}{l}\text { Percentage of } \\
\text { change }\end{array}$} \\
\hline \multicolumn{4}{|c|}{ Minute volume, $L / \min$} & $2.6 \pm 1.2$ & \multicolumn{2}{|c|}{$3.7 \pm 1.7$} & \multicolumn{2}{|c|}{$+43.7 \pm 7.8$} \\
\hline \multicolumn{4}{|c|}{$\begin{array}{l}\text { Minute work (power), } \\
1,000 \mathrm{~g}-\mathrm{cm} / \mathrm{min}\end{array}$} & $484+259$ & \multicolumn{2}{|c|}{$750 \pm 348$} & \multicolumn{2}{|c|}{$+60.8 \pm 10.0^{*}$} \\
\hline & $\begin{array}{c}404 \pm 259 \\
29 \pm 17\end{array}$ & \multirow{2}{*}{\multicolumn{2}{|c|}{$31 \pm 17$}} & \multirow{2}{*}{\multicolumn{2}{|c|}{$+10.8 \pm 4.4^{*}$}} \\
\hline & & $\mathrm{cm}$ & & $5.6 \pm 3.9$ & & & & \\
\hline \multirow{2}{*}{\multicolumn{3}{|c|}{ Pulse rate }} & & $96 \pm 29$ & \multicolumn{2}{|c|}{$\begin{array}{l}0.0 \pm 4.3 \\
122 \pm 30\end{array}$} & \multirow{4}{*}{\multicolumn{2}{|c|}{$\begin{aligned}+32.4 & \pm 10.1^{*} \\
-2.6 & \pm 3.4 \\
-24.1 & \pm 11.2^{*} \\
+7.2 & \pm 1.8^{*}\end{aligned}$}} \\
\hline \multirow{3}{*}{\multicolumn{4}{|c|}{$\begin{array}{l}\text { End-diastolic volume, } m l \\
\text { End-systolic volume (residual), } m l \\
\text { Mean ejection pressure, } \mathrm{g} / \mathrm{cm}^{2}\end{array}$}} & $54 \pm 32$ & \multirow{3}{*}{\multicolumn{2}{|c|}{$\begin{array}{r}50 \pm 24 \\
18 \pm 10 \\
190 \pm 34\end{array}$}} & & \\
\hline & & & & $25 \pm 18$ & & & & \\
\hline & & & & $178 \pm 35$ & & & & \\
\hline \multicolumn{9}{|c|}{$\begin{array}{c}\text { Comparison of individual measurements of left ventricular function during exercise, } \\
\text { expressed as percentage of the resting state, in } 14 \text { intact anesthetized dogs }\end{array}$} \\
\hline Dog no. & $\begin{array}{l}\text { End- } \\
\text { diastolic } \\
\text { volume }\end{array}$ & $\begin{array}{l}\text { End- } \\
\text { systolic } \\
\text { volume }\end{array}$ & $\begin{array}{l}\text { Stroke } \\
\text { volume }\end{array}$ & $\begin{array}{l}\text { Pulse } \\
\text { rate }\end{array}$ & $\begin{array}{l}\text { Minute } \\
\text { volume }\end{array}$ & $\begin{array}{l}\text { Stroke } \\
\text { work }\end{array}$ & $\underset{\text { work }}{\text { Minute }}$ & $\begin{array}{l}\text { Mean } \\
\text { ejection } \\
\text { pressure }\end{array}$ \\
\hline 13 & -12.8 & -34.6 & +30.8 & +28.4 & +70.0 & +58.8 & +104.3 & +16.4 \\
\hline 15 & -10.8 & -37.5 & +44.4 & $\begin{array}{r}+ \\
+\quad 2.0\end{array}$ & +46.3 & +47.1 & +50.1 & -8.2 \\
\hline 16 & -1.6 & +14.8 & -13.5 & $\begin{array}{r}+159.6 \\
\end{array}$ & +126.3 & -5.4 & +145.5 & +8.6 \\
\hline 29 & -20.8 & -52.1 & -1.3 & +11.8 & +11.5 & +12.5 & $\begin{array}{r}25.7 \\
\end{array}$ & +0.5 \\
\hline 30 & -16.0 & -49.1 & +17.0 & +50.0 & $\begin{array}{r}15.7 \\
+\quad 75\end{array}$ & +26.2 & $\begin{array}{r}+89.4 \\
\end{array}$ & $\begin{array}{r}+9.9 \\
+9\end{array}$ \\
\hline 43 & -10.0 & -61.5 & +29.4 & +25.5 & $\begin{array}{r}58.8 \\
+\quad 58\end{array}$ & $\begin{array}{r}2 \\
+71.4\end{array}$ & +115.3 & +12.5 \\
\hline 62 & -8.4 & -23.1 & \pm 0.0 & +32.3 & $\begin{array}{r}33.3 \\
\end{array}$ & $\begin{array}{r}+6.7 \\
+\quad 6.7\end{array}$ & $\begin{array}{r}4.0 \\
+\quad 41.0\end{array}$ & \pm 0.0 \\
\hline 66 & +18.8 & +28.6 & +11.1 & $\begin{array}{r}18.4 \\
+\quad 18\end{array}$ & $\begin{array}{r}28.6 \\
+\quad 28\end{array}$ & $\begin{array}{r}0.3 \\
+14.3\end{array}$ & $\begin{array}{r}3.0 \\
+\quad 35.9\end{array}$ & $\begin{array}{l}+6.0 \\
+6.5\end{array}$ \\
\hline 67 & -7.4 & -15.8 & -2.9 & +40.5 & $\begin{array}{r}34.1 \\
+\end{array}$ & +13.1 & $\begin{array}{r}58.8 \\
+\end{array}$ & +12.4 \\
\hline 76 & +14.3 & +33.3 & +6.7 & +14.1 & $\begin{array}{r}1 \\
+\quad 22.7\end{array}$ & +22.2 & $\begin{array}{r}1 \\
+\quad 39.6\end{array}$ & +14.1 \\
\hline 77 & \pm 0.0 & -20.0 & +15.0 & +16.7 & +33.3 & +26.7 & +47.9 & +6.8 \\
\hline 82 & +22.2 & +11.1 & +22.2 & -2.5 & +21.4 & +50.0 & +46.3 & +9.0 \\
\hline 84 & \pm 0.0 & -9.1 & +4.0 & +29.1 & +31.8 & +14.3 & +47.7 & +11.0 \\
\hline 87 & -4.5 & +5.6 & -11.5 & +27.6 & +14.8 & -18.3 & +4.2 & +0.8 \\
\hline Mean & -2.6 & $-24.1^{*}$ & $+10.8^{*}$ & $+32.4^{*}$ & $+43.7^{*}$ & $+24.3^{*}$ & $+60.8^{*}$ & $+7.2^{*}$ \\
\hline $\mathrm{SE}$ & \pm 3.4 & \pm 11.2 & \pm 4.4 & \pm 10.1 & $\pm \quad 7.8$ & \pm 7.0 & \pm 10.0 & \pm 1.8 \\
\hline
\end{tabular}

*Indicates significance at $95 \% \mathrm{p}$. 
TABLE II

Comparison of left ventricular function in four vagectomized dogs (average weight, $11.3 \mathrm{~kg}$ ) at rest and during mild exercise

\begin{tabular}{|c|c|c|c|c|c|c|c|c|}
\hline & & & \multicolumn{2}{|c|}{$\begin{array}{c}\text { Rest } \\
41 \text { cycles }\end{array}$} & \multicolumn{2}{|c|}{$\begin{array}{l}\text { Exercise } \\
\mathbf{4 3} \text { cycles }\end{array}$} & \multicolumn{2}{|c|}{$\begin{array}{l}\text { Percentage of } \\
\text { change }\end{array}$} \\
\hline \multicolumn{3}{|c|}{$\begin{array}{l}\text { Minute volume, } \mathrm{L} / \mathrm{min} \\
\text { Minute work, } 1,000 \mathrm{~g}-\mathrm{cm} / \mathrm{min} \\
\text { Stroke volume, } \mathrm{ml} \\
\text { Stroke work, } 1,000 \mathrm{~g}-\mathrm{cm} \\
\text { Pulse rate } \\
\text { End-diastolic volume, } \mathrm{ml} \\
\text { Mean ejection pressure, } \mathrm{g} / \mathrm{cm}^{2}\end{array}$} & \multicolumn{2}{|c|}{$\begin{aligned} 1.9 & \pm 0.6 \\
334 & \pm 235 \\
11 & \pm 4 \\
1.82 & \pm 1.07 \\
169 & \pm 29 \\
19 & \pm 8 \\
157 & \pm 31\end{aligned}$} & \multicolumn{2}{|c|}{$\begin{aligned} 2.4 & \pm 0.7 \\
409 & \pm 298 \\
14 & \pm 2 \\
2.20 & \pm 1.32 \\
166 & \pm 34 \\
22 & \pm 6 \\
143 & \pm 45\end{aligned}$} & \multicolumn{2}{|c|}{$\begin{array}{l}+29.7 \pm 9.0^{*} \\
+15.9 \pm 6.6^{*} \\
+33.5 \pm 13.1^{*} \\
+17.6 \pm 5.4^{*} \\
-2.2 \pm 2.5 \\
+27.4 \pm 13.7^{*} \\
-10.1 \pm 10.1\end{array}$} \\
\hline \multicolumn{9}{|c|}{$\begin{array}{c}\text { Comparison of individual measurements of left ventricular function during exercise, expressed as } \\
\text { percentage of the resting state, in vagectomized dogs }\end{array}$} \\
\hline Dog no. & $\begin{array}{l}\text { End- } \\
\text { diastolic } \\
\text { volume }\end{array}$ & $\begin{array}{l}\text { End- } \\
\text { systolic } \\
\text { volume }\end{array}$ & $\begin{array}{l}\text { Stroke } \\
\text { volume }\end{array}$ & $\begin{array}{l}\text { Pulse } \\
\text { rate }\end{array}$ & $\begin{array}{l}\text { Minute } \\
\text { volume }\end{array}$ & $\begin{array}{l}\text { Stroke } \\
\text { work }\end{array}$ & $\begin{array}{c}\text { Minute } \\
\text { work }\end{array}$ & $\begin{array}{l}\text { Mean } \\
\text { ejection } \\
\text { pressure }\end{array}$ \\
\hline $\begin{array}{l}37 \\
43 \\
54 \\
60\end{array}$ & $\begin{array}{l}+16.7 \\
+25.0 \\
+71.4 \\
-3.7\end{array}$ & $\begin{array}{lr} \pm & 0 \\
\pm & 0 \\
+100 \\
\pm \quad 0\end{array}$ & $\begin{array}{r}+40.0 \\
+33.3 \\
+66.7 \\
-\quad 5.9\end{array}$ & $\begin{array}{l}+4.0 \\
-3.0 \\
-9.8 \\
\pm 0\end{array}$ & $\begin{array}{l}+45.0 \\
+29.2 \\
+44.4 \\
\pm 0\end{array}$ & $\begin{array}{l}+19.0 \\
+30.1 \\
\pm 0 \\
+21.2\end{array}$ & $\begin{array}{r}+23.6 \\
+26.2 \\
+7.3 \\
+21.0\end{array}$ & $\begin{array}{l}-3.6 \\
-7.2 \\
-42.6 \\
+13.0\end{array}$ \\
\hline $\begin{array}{l}\text { Mean } \\
\text { SE }\end{array}$ & $\begin{array}{l}+27.4^{*} \\
\pm 13.7\end{array}$ & $\begin{array}{l}+25.0 \\
\pm 48.3\end{array}$ & $\begin{array}{l}+33.5^{*} \\
\pm 13.1\end{array}$ & $\begin{array}{l}-2.2 \\
\pm 2.5\end{array}$ & $\begin{array}{l}+29.7^{*} \\
\pm 9.0\end{array}$ & $\begin{array}{l}+17.6^{*} \\
\pm 5.4\end{array}$ & $\begin{array}{l}+15.9^{*} \\
\pm 6.6\end{array}$ & $\begin{array}{l}-10.1 \\
\pm 10.1\end{array}$ \\
\hline
\end{tabular}

*Indicates significance at $95 \% \mathrm{p}$.

calculated the volume of these $1.0-\mathrm{mm}$ sections according to the following formula: $V=[\pi \mathrm{h}(\mathrm{AA} \times \mathrm{BB})] / 4$, where $V=$ volume in $\mathrm{ml}, h=1.0 \mathrm{~mm}, A A=$ ventricular diameter from $\mathrm{LAO}$ view, and $B B=$ ventricular diameter from RAO view. Finally, volumes of all the sections were added to obtain the total left ventricular volume prevailing at the instant the frames were exposed. Integrated kinetic and potential work were calculated as previously described. The problems and limitations in the method have been discussed previously (10).

\section{RESULTS}

The effects of mild exercise on left ventricular function in anesthetized dogs, with autonomic control intact, are shown in Table I. The results are qualitatively similar to those reported previously by Chapman, Baker, and Mitchell (10) on six normal dogs; the data in Table I include those reported in the earlier paper. The normal response to this level of exercise is characterized by: $a$ ) slight decrease in end-diastolic volume in most animals; $b$ ) increase in stroke volume; $c$ ) increase in stroke work; and $d$ ) increase in pulse rate. It was again noted that decrease in end-diastolic volume is usually but not invariably seen in exercise at this level. The small increase in mean stroke volume represents an actual increase in 9 of the 14 dogs.
The behavior of end-systolic (residual) volume is interesting in that 30 to $60 \%$ of the diastolic volume remained at the end of ejection. The findings are thus not in keeping with the contention, restated by Westermark in 1948, that the left ventricle is "completely exhausted, or nearly so" at the end of each systole (12). The decrease in endsystolic (residual) volume during exercise suggests that the ventricular reservoir is a significant source of blood called upon by the organism with the onset of exercise.

The effect of vagectomy with and without complete atropinization is shown in Table II. As was expected, removal of vagal influences caused an immediate increase in resting pulse rate, and no further increase was noted during exercise. Another effect of vagectomy was to produce a decrease in resting end-diastolic volume, presumably as a result of marked diminution in filling time. Exercise appears to have caused end-diastolic volume to increase, in contrast to the effect usually seen in normal dogs. Stroke volume rose slightly but significantly.

Cardiac sympathectomy (Table III) also failed to abolish a response to exercise, although the response was relatively small. In contrast to the previous (vagectomized) group, there was no 
TABLE III

Left ventricular function at rest and during mild exercise in five anesthetized dogs (average weight, $14.7 \mathrm{~kg}$ ) subjected to cardiac sympathectomy

\begin{tabular}{|c|c|c|c|}
\hline & $\begin{array}{c}\text { Rest } \\
28 \text { cycles }\end{array}$ & $\begin{array}{l}\text { Exercise } \\
32 \text { cycles }\end{array}$ & $\begin{array}{c}\text { Percentage of } \\
\text { change }\end{array}$ \\
\hline $\begin{array}{l}\text { Minute volume, } \mathrm{L} / \mathrm{min} \\
\text { Minute work, } 1,000 \mathrm{~g}-\mathrm{cm} / \mathrm{min} \\
\text { Stroke volume, } \mathrm{ml} \\
\text { Stroke work, } 1,000 \mathrm{~g}-\mathrm{cm} \\
\text { Pulse rate } \\
\text { End-diastolic volume, } \mathrm{ml} \\
\text { Mean ejection pressure, } \mathrm{g} / \mathrm{cm}^{2}\end{array}$ & $\begin{aligned} 2.32 & \pm 0.63 \\
487 & \pm 150 \\
20 & \pm 7 \\
4.13 & \pm 0.87 \\
119 & \pm 28 \\
33 & \pm 7 \\
202 & \pm 36\end{aligned}$ & $\begin{aligned} 2.68 & \pm 0.57 \\
549 & \pm 151 \\
22 & \pm 7 \\
4.50 & \pm 0.87 \\
124 & \pm 23 \\
37 & \pm 8 \\
198 & \pm 43\end{aligned}$ & $\begin{array}{l}+16.4 \pm 7.2^{*} \\
+13.6 \pm 2.0 \\
+11.7 \pm 3.2^{*} \\
+9.8 \pm 4.3 \\
+4.1 \pm 5.0 \\
+14.2 \pm 2.9^{*} \\
-2.6 \pm 2.9\end{array}$ \\
\hline
\end{tabular}

Comparison of individual measurements of left ventricular function during exercise, expressed as percentage of the resting state, in sympathectomized dogs

\begin{tabular}{|c|c|c|c|c|c|c|c|c|}
\hline Dog no. & $\begin{array}{l}\text { End- } \\
\text { diastolic } \\
\text { volume }\end{array}$ & $\begin{array}{l}\text { End- } \\
\text { systolic } \\
\text { volume }\end{array}$ & $\begin{array}{l}\text { Stroke } \\
\text { volume }\end{array}$ & $\begin{array}{l}\text { Pulse } \\
\text { rate }\end{array}$ & $\begin{array}{l}\text { Minute } \\
\text { volume }\end{array}$ & $\begin{array}{l}\text { Stroke } \\
\text { work }\end{array}$ & $\begin{array}{c}\text { Minute } \\
\text { work }\end{array}$ & $\begin{array}{l}\text { Mean } \\
\text { ejection } \\
\text { pressure }\end{array}$ \\
\hline $\begin{array}{l}72 \\
77 \\
82 \\
84 \\
86\end{array}$ & $\begin{array}{r}+20.5 \\
+12.5 \\
+2.3 \\
+14.8 \\
+20.8\end{array}$ & $\begin{array}{r}+22.7 \\
+\quad 6.3 \\
-20.0 \\
+57.1 \\
+30.0\end{array}$ & $\begin{array}{l}+17.6 \\
+17.6 \\
+9.1 \\
\pm 0 \\
+14.3\end{array}$ & $\begin{array}{l}+23.2 \\
\pm 0 \\
+7.1 \\
-\quad 1.9 \\
-7.7\end{array}$ & $\begin{array}{r}+44.4 \\
+17.5 \\
+16.7 \\
+\quad 1.9 \\
+\quad 5.5\end{array}$ & $\begin{array}{r}-3.9 \\
+19.8 \\
+\quad 5.9 \\
+7.3 \\
+20.1\end{array}$ & $\begin{array}{r}+18.4 \\
+19.7 \\
+13.5 \\
+\quad 5.3 \\
+10.9\end{array}$ & $\begin{array}{l}-7.3 \\
+8.1 \\
-8.4 \\
-4.8 \\
-0.5\end{array}$ \\
\hline $\begin{array}{l}\text { Mean } \\
\text { SE }\end{array}$ & $\begin{array}{l}+14.2^{*} \\
\pm 2.9\end{array}$ & $\begin{array}{l}+19.2^{*} \\
\pm 7.6\end{array}$ & $\begin{array}{l}+11.7^{*} \\
\pm 3.2\end{array}$ & $\begin{array}{l}+4.1 \\
\pm 5.0\end{array}$ & $\begin{array}{l}+16.4^{*} \\
\pm 7.2\end{array}$ & $\begin{array}{l}+9.8^{*} \\
\pm 4.3\end{array}$ & $\begin{array}{l}+13.6^{*} \\
\pm 2.0\end{array}$ & $\begin{array}{l}-2.6 \\
\pm 2.9\end{array}$ \\
\hline
\end{tabular}

*Indicates significance at $95 \% \mathrm{p}$.

marked resting tachycardia; a slight but insignificant increase in rate was seen during exercise. Again, exercise produced small increases in minute volume, stroke volume, stroke work, and end- diastolic volume. The resting pulse rate in some dogs was, for unknown reasons, higher than expected and this may have obscured some features of response to exercise. The usual behavior of

TABLE IV

Left ventricular function at rest and during mild exercise in five anesthetized dogs with denervated hearts (average weight, $14.7 \mathrm{~kg}$ )

\begin{tabular}{|c|c|c|c|c|c|c|c|c|}
\hline & & & \multicolumn{2}{|c|}{$\begin{array}{c}\text { Rest } \\
36 \text { cycles }\end{array}$} & \multicolumn{2}{|c|}{$\begin{array}{l}\text { Exercise } \\
34 \text { cycles }\end{array}$} & \multicolumn{2}{|c|}{$\begin{array}{l}\text { Percentage of } \\
\text { change }\end{array}$} \\
\hline \multicolumn{3}{|c|}{$\begin{array}{l}\text { Minute volume, } \mathrm{L} / \mathrm{min} \\
\text { Minute work, } 1,000 \mathrm{~g}-\mathrm{cm} / \mathrm{min} \\
\text { Stroke volume, } \mathrm{ml} \\
\text { Stroke work, } 1,000 \mathrm{~g}-\mathrm{cm} \\
\text { Pulse rate } \\
\text { End-diastolic volume, } \mathrm{ml} \\
\text { Mean ejection pressure, } \mathrm{g} / \mathrm{cm}^{2}\end{array}$} & \multicolumn{2}{|c|}{$\begin{aligned} 2.00 & \pm 0.36 \\
339 & \pm 96 \\
15 & \pm 2 \\
2.88 & \pm 0.53 \\
131 & \pm 19 \\
26 & \pm 3 \\
189 & \pm 28\end{aligned}$} & \multicolumn{2}{|c|}{$\begin{aligned} 2.43 & \pm 0.52 \\
467 & \pm 144 \\
19 & \pm 5 \\
3.77 & \pm 0.68 \\
131 & \pm 20 \\
29 & \pm 1 \\
184 & \pm 34\end{aligned}$} & \multicolumn{2}{|c|}{$\begin{array}{l}+21.7 \pm 7.7^{*} \\
+32.8 \pm 12.4^{*} \\
+23.8 \pm 6.9^{*} \\
+33.0 \pm 11.1^{*} \\
-0.4 \pm 2.7 \\
+13.4 \pm 7.3 \\
-1.8 \pm 6.2\end{array}$} \\
\hline \multicolumn{9}{|c|}{$\begin{array}{c}\text { Comparison of individual measurements of left ventricular function during exercise, expressed } \\
\text { as percentage of the resting state, in totally denervated dogs }\end{array}$} \\
\hline Dog no. & $\begin{array}{l}\text { End- } \\
\text { diastolic } \\
\text { volume }\end{array}$ & $\begin{array}{l}\text { End- } \\
\text { systolic } \\
\text { volume }\end{array}$ & $\begin{array}{l}\text { Stroke } \\
\text { volume }\end{array}$ & $\begin{array}{l}\text { Pulse } \\
\text { rate }\end{array}$ & $\begin{array}{l}\text { Minute } \\
\text { volume }\end{array}$ & $\begin{array}{c}\text { Stroke } \\
\text { work }\end{array}$ & $\begin{array}{l}\text { Minute } \\
\text { work }\end{array}$ & $\begin{array}{l}\text { Mean } \\
\text { ejection } \\
\text { pressure }\end{array}$ \\
\hline $\begin{array}{l}72 \\
77 \\
82 \\
84 \\
86\end{array}$ & $\begin{array}{l}-10.0 \\
+0 \\
+29.2 \\
+16.0 \\
+31.8\end{array}$ & $\begin{array}{l}-17.6 \\
-15.4 \\
\pm 0 \\
-22.2 \\
+33.3\end{array}$ & $\begin{array}{l} \pm 0 \\
+11.8 \\
+38.9 \\
+37.5 \\
+30.8\end{array}$ & $\begin{array}{l}-2.7 \\
\pm 0 \\
-8.5 \\
+0.6 \\
+8.7\end{array}$ & $\begin{array}{r}-1.6 \\
+\quad 7.5 \\
+22.3 \\
+38.6 \\
+41.8\end{array}$ & $\begin{array}{r}+1.5 \\
+\quad 5.2 \\
+53.4 \\
+45.4 \\
+59.5\end{array}$ & $\begin{array}{r}-1.3 \\
+\quad 4.9 \\
+39.9 \\
+47.0 \\
+73.3\end{array}$ & $\begin{array}{r}-1.0 \\
+3.4 \\
+10.5 \\
+\quad 5.8 \\
-27.7\end{array}$ \\
\hline $\begin{array}{l}\text { Mean } \\
\text { SE }\end{array}$ & $\begin{array}{l}+13.4 \\
\pm 7.3\end{array}$ & $\begin{array}{l}-4.4 \\
\pm 9.3\end{array}$ & $\begin{array}{l}+23.8^{*} \\
\pm 6.9\end{array}$ & $\begin{array}{l}-0.4 \\
\pm 2.7\end{array}$ & $\begin{array}{l}+21.7^{*} \\
\pm 7.7\end{array}$ & $\begin{array}{l}+33.0^{*} \\
\pm 11.1\end{array}$ & $\begin{array}{l}+32.8^{*} \\
\pm 12.4\end{array}$ & $\begin{array}{r}1.8 \\
\pm 6.2\end{array}$ \\
\hline
\end{tabular}

* Indicates significance at $95 \% \mathrm{p}$. 
pulse rate in the dog, as shown by Hunt many years ago, is to decline when sympathetic influences are removed. He found the resting rate of the intact dog to be 102 ; vagectomy caused it to increase to 174 , and sympathectomy produced a decline to 96 (13).

In the animals with total cardiac denervation (Table IV), exercise produced an increase in all variables that were measured except for pulse rate and mean ejection pressure. Comparison with the intact group shows the following differences. a) Response in terms of minute volume was less, and in terms of stroke volume larger, in the denervated than in the intact group. b) Enddiastolic volume increased in the denervated group as a result of exercise. In the intact group it declined or was unchanged.

\section{DISCUSSION}

The studies support the view that elimination of rate response by denervation procedures does not entirely deprive the anesthetized $\operatorname{dog}$ of its ability to respond to exercise by increasing left ventricular minute volume and work. Some property of the myocardium itself still remains, as shown in Table $\mathrm{V}$, since the response to exercise after denervation of the heart is attributable solely to increase in stroke volume. The property as conceived by Starling is represented by increase in contractile force in response to increase in enddiastolic fiber length. Rosenblueth, Alanis, Lopez, and Rubio (14), on the basis of studies using isolated heart preparations, consider that increase in contractile force is not always a function solely of end-diastolic fiber length (or volume). It may vary with the "compression volume" which, itself, may vary without alteration of end-diastolic fiber length, and is conditioned in a fundamental way by the immediately previous state of ventricular activity. The work by Rosenblueth and his group does not supplant the Starling hypothesis but, as they point out. extends and amplifies it.

Whatever the nature of the intrinsic myocardial factor, it seems clear that elimination of autonomic neural connections of the heart in otherwise intact dogs does not eliminate left ventricular response to exercise, although it does abolish participation of increase in rate in the response. It would appear that the response of the denervated
TABLE V

Percentage of change due to exercise in various manifestations of left ventricular function in anesthetized, intact dogs and in animals with incomplete or absent autonomic connections to the heart

\begin{tabular}{lcccc}
\hline \hline & Normal & $\begin{array}{c}\text { Vagec- } \\
\text { tomized }\end{array}$ & $\begin{array}{c}\text { Sympa- } \\
\text { thec- } \\
\text { tomized }\end{array}$ & $\begin{array}{c}\text { Totally } \\
\text { dener- } \\
\text { vated }\end{array}$ \\
\hline Minute volume & $+44 \%^{*}$ & $+30 \%^{*}$ & $+16 \% \dagger$ & $+22 \% \dagger$ \\
Minute work & $+61 \%^{*}$ & $+16 \%^{\dagger}$ & $+14 \%^{*}$ & $+33 \%^{\dagger}$ \\
Stroke volume & $+11 \%^{\dagger}$ & $+34 \%^{\dagger}$ & $+12 \%^{*}$ & $+24 \%^{*}$ \\
Stroke work & $+24 \%^{*}$ & $+18 \%^{*}$ & $+10 \% \dagger$ & $+33 \%^{*}$ \\
Pulse rate & $+33 \%^{*}$ & $\mathrm{NS}$ & $\mathrm{NS}$ & $\mathrm{NS}$ \\
End-diastolic volume & $\mathrm{NS}$ & $+27 \%^{+}$ & $+14 \%^{*}$ & $\mathrm{NS}$ \\
Mean ejection pressure & $+7 \dagger^{\dagger}$ & $\mathrm{NS}$ & $\mathrm{NS}$ & $\mathrm{NS}$
\end{tabular}

* At least 3 times the $\mathrm{SE}$ of the mean.

+ At least 2 times the $\mathrm{SE}$ of the mean.

left ventricle to exercise is less, quantitatively, than that seen in intact dogs under the same experimental circumstances. The response is, nonetheless, quite definite.

The possibility remains that myocardial response in the dogs with denervated hearts is attributable, not to truly intrinsic factors, but to the effect of adrenal medullary or other vasoactive hormones reaching it via the coronary arterial circulation. The experimental design employed in the present studies does not eliminate the possibility. It is known, however, that adrenal medullary hormonal outflow in response to exercise at comparably low levels is extremely small (15). It has also been clearly shown that medullary hormones characteristically produce increase in rate and decrease in end-diastolic volume (16). For these reasons it seems unlikely that the increase in stroke volume seen in dogs with denervated hearts can be attributed entirely, if at all, to adrenal medullary outflow during exercise.

To what mechanism, then, can the observed increase in left ventricular stroke volume be assigned? It may, of course, be attributable entirely, as in the Starling experiments, to the effect of increased ventricular filling under circumstances in which the ventricle, deprived of its autonomic (and especially of its sympathetic) connections, increases both its end-diastolic and its stroke volume. Some of the factors postulated by Rosenblueth and co-workers (14) may also be involved. Their compression volume factor. arterial pressure factor, and frequency (rate) factor would not seem to be applicable in this study, but the influence of previous activity may 
enter the complex picture once ventricular response has been initiated by some other mechanism. It may supplement the initial effect of increased ventricular filling.

Finally, comparison of the effects of vagectomy alone with those of sympathectomy alone is of some interest, although very difficult with the present material; it suggests, however, that the totally denervated preparation responded more effectively than did those with cardiac sympathectomy or vagectomy alone.

\section{SUMMARY AND CONCLUSIONS}

1. In dogs with cardiac sympathectomy, vagectomy, or total cardiac denervation, the left ventricle remains able to respond to exercise by an increase in cardiac output and integrated minute work.

2. The intrinsic myocardial factors, whereby these animals respond to exercise, are not solely a property of the isolated heart-lung preparation.

3 . The response of the left ventricle to exercise under these circumstances appears, by elimination, to be initiated by increased ventricular filling.

\section{REFERENCES}

1. Starling, E. H. The Linacre Lecture on the Law of the Heart, Cambridge, 1915 . New York, Longmans, Green, 1918.

2. Starling, E. H. The Law of the Heart. Lancet 1921, 2, 212.

3. Rushmer, R. F. Constancy of stroke volume in ventricular responses to exertion. Amer. J. Physiol. 1959, 196, 745.

4. Chapman, C. B., J. N. Fisher, and B. J. Sproule. Behavior of stroke volume at rest and during exercise in human beings. J. clin. Invest. 1960, 39, 1208.
5. Rushmer, R. F. Postural effects on the baselines of ventricular performance. Circulation 1959, 20, 897.

6. Chapman, C. B., T. A. Bruce, O. Baker, and J. Fisher. The effect of partial and total denervation of the heart on left ventricular function (abstract). J. clin. Invest. 1960, 39, 976.

7. Ashkar, E., and W. F. Hamilton. Effect of heart denervation and thoracoabdominal sympathectomy on some cardiovascular functions at rest and exercise (abstract). Physiologist 1961, 4, 6.

8. Donald, D., and J. T. Shepherd. Heart rate and cardiac output in exercising dogs after partial and complete cardiac denervation (abstract). Physiologist 1961, 4, 29.

9. Chapman, C. B., O. Baker, J. Reynolds, and F. J. Bonte. Use of biplane cinefluorography for measurement of ventricular volume. Circulation 1958, 18, 1105.

10. Chapman, C. B., O. Baker, and J. H. Mitchell. Left ventricular function at rest and during exercise. J. clin. Invest. 1959, 38, 1202.

11. Baker, O., J. Khalaf, and C. B. Chapman. A scannercomputer for determining the volumes of cardiac chambers from cinefluorographic films. Amer. Heart J. 1961, 62, 797.

12. Westermark, N. Studies of the circulation by roentgencinematography. Radiology 1948, 50, 791.

13. Hunt, R. Direct and reflex acceleration of the mammalian heart with some observations on the relations of the inhibitory and accelerator nerves. Amer. J. Physiol. 1899, 2, 395.

14. Rosenblueth, A., J. Alanis, E. Lopez, and R. Rubio. The adaptation of ventricular muscle to different circulatory conditions. Arch. int. Physiol. 1959, 67, 358.

15. Gray, I., and W. P. Beetham, Jr. Changes in plasma concentration of epinephrine and norepinephrine with muscular work. Proc. Soc. exp. Biol. (N. Y.) 1957, 96, 636.

16. Katz, A. M., L. N. Katz, and F. L. Williams. Registration of left ventricular volume curves in the dog with the systemic circulation intact. Circulat. Res. $1955,3,588$. 